\title{
An Analysis of Network Structure in Mazda's Yokokai using the DEC Spatial Model
}

\author{
T. Ito, S. Tagawa, S. Matsuno, Y. Uchida \\ Dept. of Business Administration \\ Ube National College of Technology \\ Ube City, Japan
}

\author{
Rajiv Mehta \\ School of Management \\ New Jersey Institute of Technology \\ Newark, New jersey, USA
}

\author{
Makoto Sakamoto, Satoshi Ikeda \\ Faculty of Engineering \\ University of Miyazaki \\ Miyazaki City, Japan
}

Received: June 22, 2019. Revised: July 30, 2021. Accepted: September 10, 2021. Published: November 26, 2021.

\begin{abstract}
By examining networks is possible to understand the nature of inter-firm relationships among organizational entities in any given corporate group, such as Toyota's, Nissan's or Mazda's Keiretsu. Recently, a new three-dimensional spatial model has been developed that allows organizational scholars to ascertain the structure of a corporate group, the position of the individual firms, and the determinants of the firm performance. This new spatial paradigm -called the DEC spatial modelcomposed of degree, effective size and capacity that assessed the relationship between Euclidean distance and sales. Although it advances our understanding of networks, the bulk of the research is based on cross-sectional data, it is not possible ascertain the real nature of the relationship between the distance and sales. Instead, the analysis of networks requires using time series data as all the corporate members of a network are ongoing-concerns. To augment our understanding of the nature of inter-firms networks, the interrelationship between distance and sales is examined using time series data drawn from Mazda's Yokokai in 1986, 2004 and 2005. More specifically, in this paper the data on transactions were collected and used to calculate the Euclidean distance using the DEC spatial model. The position and its determinants of all individual firms are identified and the trend of structure changes is discussed. Based on the findings of offered and avenues of future research are suggested.
\end{abstract}

Keywords-Network, Strategy, the DEC, Keiretsu, Sales, Euclidean distance, three-dimensional spatial model, Yokokai

\section{INTRODUCTION}

A different viewpoint of corporate strategy between Porter and Barney is that corporate strategy is determined by the internal factors or external factors. The former is called positioning school and the latter is called resource-based view. Five forces, rivalry among existing firms, potential entrants, substitutes, and bargaining power of suppliers and buyers, are the determinants of getting the competitive advantage in Porter's theory [1]. Meanwhile, Barney stressed that VRIN (valuable, rare, in-imitable and non-substitutable) characteristics of managerial resources is the key factor of a sustainable competitive advantage [2]. However, based upon network perspective, the common character of these two typical theories can be considered as the view of relationship. Nowadays external inter-firms relationship is becoming more important than internal resources coordination because of uncertainty and the flood of information. One of the successful external relationships is Japanese network, called Keiretsu.

In this paper, we reviewed the literature of the network research and corporate strategy, and discussed the new approach called DEC spatial model. Furthermore, we collected the data from Mazda's Keiretsu, Yokokai and analyzed the relationship between Euclidean distance and sales. Finally we discussed the implication of the results, and found that to keep dynamic organizational form is the key factor of the successful strategy formulation.

The main contribution of this paper is that the new approach of three-dimensional spatial model is proposed, and the relationship between Euclidean spatial distance and corporate performance is analyzed.

\section{BACKGROUND}

Widely accepted as being successful, keiretsus are made-up of affiliated firms that are ordered and characterized by longterm continuous rationality, trade exclusivity, and information concealment. However, cross shareholdings as reflected by the percent and amount of stock cross ownership, which is also known to be a central facet of keiretsus, is being abandoned. As a result, carmakers are losing control of their crucial auto-parts suppliers, who are now increasingly focusing on developing their customer base by selling to non-network members. Largely owed to a condition referred to as keiretsu loosening, the inter-organizational network of suppliers and carmakers now has begun to resemble an affiliated group company network rather than a classic keiretsu. This phenomenon of keiretsu loosening begs the following questions: What kind of 
inter-firm relationships will be most effective in improving corporate performance?

Of the plethora of studies that have focused on strategy formulation, two aspects are noteworthy: coordination of managerial resources within firm and establishment of rational relationships with outside shareholdings. Evidently, as interfirm relationships with external constituents are important, the network perspective can effectively increase our collective understanding of the dynamics between network members. Recent investigations on inter-firm relationships have focused on examining centrality [3], the relationship between corporate governance and closeness [4], firm centrality measurement of transaction and cross-shareholdings and capacity index $[5,6]$. Furthermore, a study on the relationship between corporate strategy and three-dimension network has been reported [7]. Recently, a new approach embedded in three-dimensional space comprising degree, effective size, and capacity, called DEC spatial model is proposed by Ito et al. [8]. This DEC spatial model calculates the Euclidean distance among firms, which is then used to analyze the rational interrelationships between Euclidean distance and sales (a corporate performance index) using transactional data gathered from Mazda's Yokokai. In this paper, we introduced direction into the model and proposed the new framework of this model under the discussion of the three network indices.

\section{MODEL AND DATA COLLECTION}

The DEC model can be illustrated as follows.

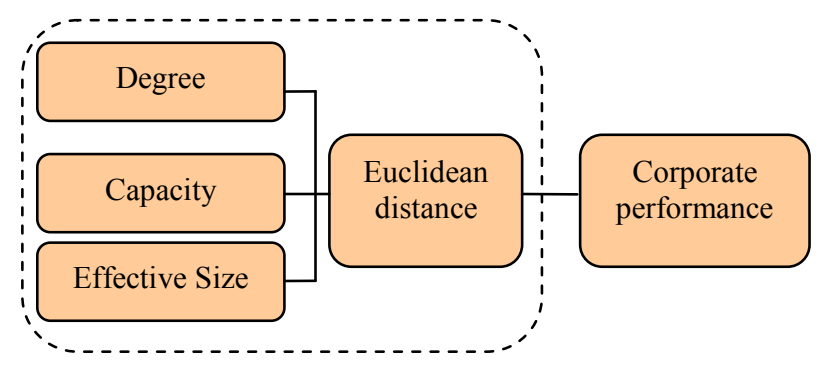

Fig. 1. Framework of the DEC model

All three indices is the solid foundation of the model. The Euclidean distance will be calculated based upon the three indices. Strategy factors will be determined after the regression analysis between Euclidean distance and corporate performance.

\section{A. Measurement}

The detailed calculation of the three network indices are as follows.

\section{1) Degree}

Degree is defined as the number of nodes that connect with it directly. It will be calculated as follows [9].

$$
C_{D}\left(p_{k}\right)=\sum_{i=1}^{n} a\left(p_{i}, p_{k}\right)
$$

where

$$
\mathrm{k}=1,2,3, \ldots \ldots, \mathrm{n}
$$

$\mathrm{a}\left(\mathrm{p}_{\mathrm{i}}, \mathrm{p}_{\mathrm{k}}\right)=1$, if and only if $\mathrm{p}_{\mathrm{i}}$ and $\mathrm{p}_{\mathrm{k}}$ are connected by a line

$\mathrm{a}\left(\mathrm{p}_{\mathrm{i}}, \mathrm{p}_{\mathrm{k}}\right)=0$, otherwise

Degree generally can be considered as the index of communication. In an asymmetric model, degree will be divided into two parts: out-degree and in-degree.

\section{2) Effective size}

Effective size is network size (n) minus redundancy in network. It can be calculated as follows [10].

$$
E S_{i}=\sum_{j}\left[1-\sum_{q} p_{i q} m_{j q}\right]
$$

where

$$
\mathrm{q} \neq \mathrm{i}, \mathrm{j}
$$

$\mathrm{m}_{\mathrm{jq}}$ : i's interaction with $\mathrm{q}$ divided by j's strongest relationship with node

$\mathrm{p}_{\mathrm{iq}}$ : proportion of I's energy invested in relationship with $\mathrm{q}$

\section{3) Capacity}

Capacity is an index to calculate the numbers of connection line between any two nodes under the consumption of when the length of the path between two nodes equals to $r$, the value of the length $r$ should be higher than $r+1$. In other words, it holds that the value of the capacity is higher, the bigger capacity we have. It can be calculated as follows if the length of $r$ is equal to infinity.

$$
C=\left(I-\left(\frac{A}{\eta}\right)\right)^{-1}-I
$$

where
A: Adjacency matrix
I: Identity matrix
$\eta$ : Parameter of distance

In an asymmetric model, degree will be divided into two parts: out-capacity and in-capacity.

\section{4) Euclidean Spatial Distance}

Euclidean spatial distance is defined as the length of the line connecting any two nodes. It can be calculated as follows.

$$
d_{i j}=\sqrt{\left(C_{D}\left(p_{i}\right)-C_{D}\left(p_{j}\right)\right)^{2}+\left(E S_{i}-E S_{j}\right)^{2}+\left(C_{i}-C_{j}\right)^{2}}
$$

\section{B. Data Collection}

To test the interrelationships among the focal constructs, data for fiscal year 2005 was drawn from Mazda's Yokokai keiretsu. In 2005, 11 carmakers and 180 suppliers are included 
in Yokokai. The list of the suppliers and carmakers in Yokokai is shown in Table I.

TABLE I. Mazda and its suppliers in Yokokai (selected part)

\begin{tabular}{|l|l|}
\hline No. & \multicolumn{1}{|c|}{ Firm } \\
\hline $\mathbf{1}$ & Mazda Motor Corporation \\
\hline $\mathbf{2}$ & Asteer Co., Ltd. \\
\hline $\mathbf{3}$ & Ishizaki Honten Company, Limited \\
\hline $\mathbf{4}$ & Uchiyama Manufacturing Corp. \\
\hline $\mathbf{5}$ & Ube Industries, Ltd. \\
\hline $\mathbf{6}$ & Ohmori Technos Co., Ltd. \\
\hline $\mathbf{7}$ & Ogino Industry Co., Ltd. \\
\hline $\mathbf{8}$ & Ondo Corporation \\
\hline $\mathbf{9}$ & Kautex Textron Keylex Co., Ltd. \\
\hline $\mathbf{1 0}$ & Kainan Iron Works Co., Ltd. \\
\hline $\mathbf{1 1}$ & Katayama Kogyou Co., Ltd. \\
\hline $\mathbf{1 2}$ & Kawakami Iron Works Co., Ltd. \\
\hline $\mathbf{1 3}$ & Kawada Corporation \\
\hline $\mathbf{1 4}$ & Kanda Co., Ltd. \\
\hline $\mathbf{1 5}$ & Keylex Corporation \\
\hline $\mathbf{1 6}$ & Kitagawa Iron Works Co., Ltd. \\
\hline
\end{tabular}

Any firm included in transaction network that has no a ny relationship with other firm is called a singleton. 89 suppliers are singletons. Transactional relationship of the 102 firms can be illustrated as Figure 2.

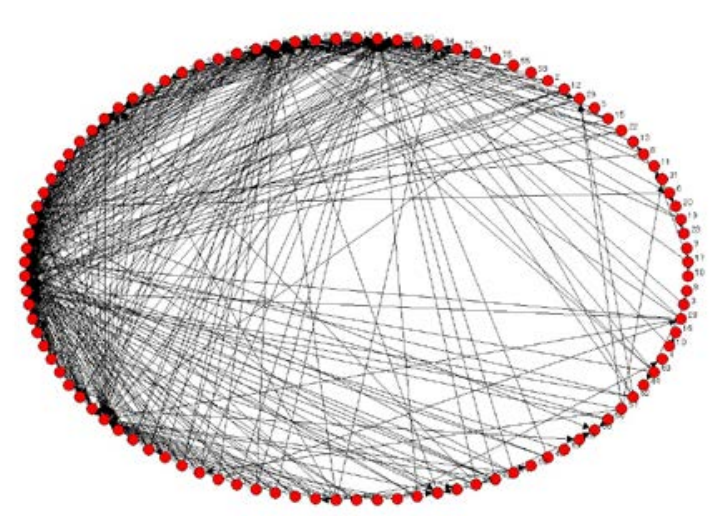

Fig. 2. Transactional network of Yokokai in 2005

We put all data in a matrix table. Yokokai is an asymmetric matrix. Thus we will calculate out-degree and indegree in degree index, and out-capacity and in-capacity in capacity index. In the matrix below, the amount in $(i, j)$ th cell means the firm in ith column sells parts to the firm in jth row, or the firm in jth row purchases parts from the firm in ith row.
TABLE II. TRANSACTIONAL MATRIX OF THE YOKOKAI

\begin{tabular}{|r||r|r|r|r|r|r|r|}
\hline & $\mathbf{1 8 1}$ & $\mathbf{1 8 2}$ & $\mathbf{1 8 3}$ & $\mathbf{1 8 4}$ & $\mathbf{1 8 5}$ & $\mathbf{1 8 6}$ & $\mathbf{1 8 7}$ \\
\hline $\mathbf{7 5}$ & 0 & 9.1 & 4.9 & 0 & 5.9 & 0 & 0 \\
\hline $\mathbf{7 6}$ & 0 & 0 & 0 & 1.6 & 0 & 1.7 & 0 \\
\hline $\mathbf{7 7}$ & 0 & 4.7 & 1.6 & 0 & 0 & 3 & 0 \\
\hline $\mathbf{7 8}$ & 0 & 0 & 0 & 0 & 0 & 0 & 0 \\
\hline $\mathbf{7 9}$ & 0 & 0 & 0 & 0 & 0 & 0 & 0 \\
\hline $\mathbf{8 0}$ & 0 & 0 & 0 & 0 & 0 & 0 & 0 \\
\hline $\mathbf{8 1}$ & 0 & 44.1 & 8.2 & 3.6 & 3.9 & 4.8 & 4.3 \\
\hline $\mathbf{8 2}$ & 0 & 6.3 & 9.7 & 18.7 & 1.7 & 6 & 0 \\
\hline $\mathbf{8 3}$ & 0 & 0 & 0 & 0 & 0 & 0 & 0 \\
\hline $\mathbf{8 4}$ & 0 & 0 & 51.6 & 0 & 20.5 & 4.1 & 0 \\
\hline
\end{tabular}

Therefore, out-degree means the firm sells its parts to other firms, and in-degree means that the firm purchases the parts from other firms.

Before our calculation, we collected the data including both of amount and percent from the transaction network, and analyzed the correlation with sales. As all correlation coefficients are significant $(\mathrm{p}<0.5)$, thus percentage data is used in this paper.

\section{RESUlTS AND DisCUSSION}

Based upon the methods shown in Section 3.1, we calculated degree, effective size, and capacity. The results are shown in Table III.

TABLE III. RESULTS OF THE DEC INDICES (SELECTED PART)

\begin{tabular}{|r|r|r|r|r|r|}
\hline No. & $\begin{array}{l}\text { Out- } \\
\text { degree }\end{array}$ & $\begin{array}{l}\text { In- } \\
\text { degree }\end{array}$ & $\begin{array}{l}\text { Effective } \\
\text { Size }\end{array}$ & $\begin{array}{l}\text { In- } \\
\text { capacity }\end{array}$ & $\begin{array}{l}\text { Out- } \\
\text { capacity }\end{array}$ \\
\hline $\mathbf{1}$ & 0 & 1021.74 & 58.76 & 0 & 10.3312 \\
\hline $\mathbf{2}$ & 99.48 & 0 & 3 & 0.975294 & 0 \\
\hline $\mathbf{3}$ & 68 & 0 & 2 & 0.666667 & 0 \\
\hline $\mathbf{4}$ & 0 & 12 & 1 & 0 & 0.117647 \\
\hline $\mathbf{5}$ & 87.3 & 0 & 1 & 0.855882 & 0 \\
\hline $\mathbf{6}$ & 61.2 & 0 & 2.167 & 0.616449 & 0 \\
\hline $\mathbf{7}$ & 0 & 3.8 & 1 & 0 & 0.037255 \\
\hline $\mathbf{8}$ & 86.3 & 0 & 2.125 & 0.880917 & 0 \\
\hline $\mathbf{9}$ & 0 & 10.8 & 1 & 0 & 0.105882 \\
\hline $\mathbf{1 0}$ & 79.1 & 0 & 3 & 0.77549 & 0 \\
\hline
\end{tabular}

We calculated partial correlation coefficient of the five indices in multiple regression model, and found out-degree, incapacity are not significant. Thus we removed those two variables and recalculated the regression model again. The results are shown in Table IV. 
TABLE IV. RESUlts of THE VARIANCE ANALYSIS

\begin{tabular}{|l|r|r|r|c|}
\hline & \multicolumn{1}{|c|}{$\begin{array}{c}\text { Sum of } \\
\text { Squares }\end{array}$} & $\begin{array}{c}\text { Degree of } \\
\text { Freedom }\end{array}$ & $\begin{array}{c}\text { Mean } \\
\text { Square }\end{array}$ & F Test \\
\hline Total & $1.2992 \mathrm{E}+13$ & 77 & & 44.132 \\
\hline $\begin{array}{l}\text { Regressio } \\
\mathbf{n}\end{array}$ & $8.3337 \mathrm{E}+12$ & 3 & $2.7779 \mathrm{E}+12$ & Prob. \\
\hline Residual & $4.6579 \mathrm{E}+12$ & 74 & $6.2945 \mathrm{E}+10$ & 0.000 \\
\hline
\end{tabular}

Coefficient of determination: 0.64147

Multiple correlation coefficient: 0.80092

Adjusted R-square: 0.79179

AIC: $2,164.76$

DW ratio: 1.9709

From Table IV, the coefficient of determination is 0.64147 , and DW ratio is 1.9709. Therefore, the regression model is significant. The estimation of regression coefficients is shown in Table V.

TABLE V. ESTIMATION OF REGRESSION COEFFICIENTS

\begin{tabular}{|c|c|c|c|c|}
\hline & $\begin{array}{c}\text { In- } \\
\text { degree }\end{array}$ & $\begin{array}{c}\text { Effective } \\
\text { size }\end{array}$ & $\begin{array}{c}\text { Out- } \\
\text { capacity }\end{array}$ & $\begin{array}{c}\text { Intercep } \\
\mathbf{t} \\
\end{array}$ \\
\hline $\begin{array}{l}\text { Partial } \\
\text { correlation } \\
\text { coefficient }\end{array}$ & $\begin{array}{r}-3.41867 \\
E+6\end{array}$ & $\begin{array}{r}2.11997 \\
E+4\end{array}$ & $\begin{array}{r}3.49078 \\
E+8\end{array}$ & 226.234 \\
\hline $\begin{array}{l}\text { Standard } \\
\text { coefficient }\end{array}$ & -191.885 & 0.1718 & 192.503 & 0.0000 \\
\hline T value & -5.2490 & 2.2356 & 5.2657 & 0.0038 \\
\hline $\begin{array}{l}\text { Degree of } \\
\text { Freedom }\end{array}$ & 74 & 74 & 74 & 74 \\
\hline Prob. & 0.0000 & 0.0284 & 0.0000 & \multirow[t]{2}{*}{0.9970} \\
\hline $\begin{array}{l}\text { Correlation } \\
\text { coefficient }\end{array}$ & 0.6904 & 0.4490 & 0.6912 & \\
\hline
\end{tabular}

Partial correlation coefficient of in-degree is negative in Table 5. It means that the in-degree is inversely proportional to sales. Therefore, as in-degree increase, sales decrease. It corroborates the fact that directly dealing with multiple firms will aid to improve corporate performance. Partial correlation coefficients of effective size and out-capacity are positive. This means that effective size and selling capacity have strong impact on sales.

Based upon the results, we calculated the Euclidean spatial distance between Mazda and other all firms. The result is shown as below.

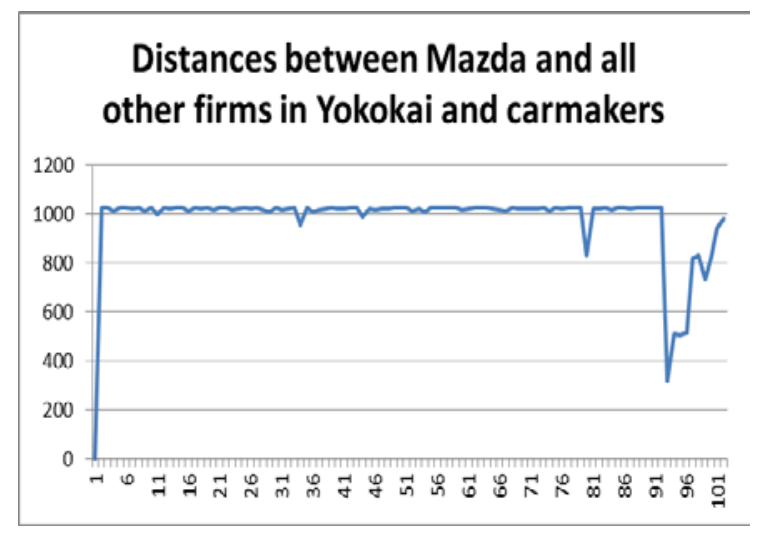

Fig. 3. Distance between Mazda and all other firms
In order to identify the relationship between distances and sales, one of the indices of corporate performance, we collected sales data of the fiscal year 2005 from Mazda Yokokai, and calculated the relationship between distances and sales. The result is shown in Table IV.

TABLE VI. COEFFICIENS OF DISTANCE-SALES REGRESSION MODEL

\begin{tabular}{|l|r|}
\hline & Distance from Mazda \\
\hline Partial regression coefficient & $-1.2297 \mathrm{E}+4$ \\
\hline Intercept & $1.2713 \mathrm{E}+7$ \\
\hline Coefficient of determination & 0.47827 \\
\hline Multiple correlation coefficient & 0.69157 \\
\hline Adjusted R- square & 0.68659 \\
\hline F value & 69.66792 \\
\hline Degree of Freedom & 1,76 \\
\hline Probability & 0.000 \\
\hline AIC & 2190.02 \\
\hline DW ratio & 2.067 \\
\hline
\end{tabular}

In Table IV, we note that the coefficient of determination is high, and the probability is zero. This means that the regression model is effective. This result accords with the findings using the 1986 data-set [8].

Apparently, during the period of 1986 and 2005, Euclidean spatial distance, based upon in-degree, effective size and outcapacity, has strong impact on sales. Therefore, adjust its position in a given group, is one of the important way to improve its performance.

\section{CONCLUSION}

In this paper, we collected the transactional data from Yokokai. Based upon the three network indices of degree, effective size and capacity, we calculated the Euclidean distances between Mazda and all other firms and other carmakers. We found that in-degree and in-capacity is not effective factor to explain the sales of each firms. And we found that the distances between Mazda and all other firms have strong impact on sales, one of the indices of corporate performance. One limitation of this paper is only three years data: 1986, 2004 and 2005 are collected and analyzed in this paper. To understand the trend of the Keiretsu changes, much more data is required.

\section{ACKNOWLEDGMENT}

This work was supported by JSPS KAKENHI Grant Number 24510217 page.

\section{REFERENCES}

[1] Porter M. E., The Five Competitive Forces That Shape Strategy, Harvard Business Review, pp.25-40, January 2008

[2] Barney J. B., Firm resources and Sustained Competitive Advantage, Journal of Management, 17, (1), pp.99-120 
[3] T. Ito, S. Matsuno, T. Ryo, A. Tan, M. Sakamoto, Measurement and analysis of group centrality index in Yokokai, Production Management, Vol. 18, No. 1, pp.61-66, 2011, Transactions of the Japan Society for Production Management (Japanese edition).

[4] T Ito and C. Medlin, Network Governance: Network Closeness and Firm Performance, Globalisation, Governance and Ethics: New Managerial and Economic Insights, J. M. Aurifeille, C. J. Medlin, \& C. Tisdell (Eds.), Chapter 10, pp.125-142, Nova Science, 2009.

[5] T. Ito, E. Niki, R. Takida, R. Mehta, K. Passerini, and M. Sakamoto, Transactions and cross shareholdings in Mazda's Keiretsu: a centrality analysis, Artificial Life and Robotics, Volume 16, Number 3, pp.297300, Springer Japan, 2012.

[6] T. Ito, R. Takida, S. Matsuno, R. Mehta, Y. Ishida, and M. Sakamoto, An analysis of a firm's capacity in Mazda's
Keiretsu, Artificial life and robotics, Volume 16, Number 2, 2001, pp. 248-252, Springer Japan.

[7] T. Ito, H. Oka, E. Niki, and M. Sakamoto, Development and research on three dimension corporate strategy, Memoirs of the Faculty of Engineering, University of Miyazaki, Vol. 38, pp. 313-318, 2009.

[8] T. Ito, S. Matsuno, R. Mehta, M. Sakamoto, and S. Ikeda, An analysis of inter-firms distances and corporate performance using DEC spatial Model, Recent advances in Energy \& Environment Integrated Systems, Proceedings of the $2^{\text {nd }}$ International Conference on Integrated Systems and Management for Energy, Development, Environment and Health (ISMAEDEH '13), Morioka City Iwate, Japan April 23-25, 2013, pp.8085

[9] J. Nieminen, On centrality in a graph, Scandinavian Journal of Psychology, 15, pp. 322-336, 1974.

[10] R. S. Burt, Structure Holes. 1992, Harvard University Press.

\section{Creative Commons Attribution License 4.0} (Attribution 4.0 International, CC BY 4.0)

This article is published under the terms of the Creative Commons Attribution License 4.0

https://creativecommons.org/licenses/by/4.0/deed.en_US 